\title{
Anesthesia of Biomphalaria spp. (Mollusca, Gastropoda): Sodium Pentobarbital is the Drug of Choice
}

\author{
RL Martins-Sousa/ ${ }^{++}$, D Negrão-Corrêa/ ${ }^{+} /++$, FSM Bezerra*, PMZ Coelho**/++
}

Departamento de Parasitologia, Instituto de Ciências Biológicas, Universidade Federal de Minas Gerais,

Av. Antônio Carlos 6627, 31270-901 Belo Horizonte, MG, Brasil *Departamento de Análises Clínicas e Toxicológicas, Faculdade de Farmácia, Odontologia e Enfermagem, Universidade Federal do Ceará, Fortaleza,

CE, Brasil **Santa Casa de Misericórdia, Belo Horizonte, MG, Brasil

The anesthetic effect of some water-soluble anesthesic or narcotic drugs currently used in mice was tested in molluscs of the Biomphalaria genus.

Sodium thiopental was very toxic to the snails resulting in high rates of mortality in all the treatment schedules tested. Cetamine base, at concentration of $0.25 \mathrm{mg} / \mathrm{ml}$ of water, resulted in partial snail anesthesia (40\% of snails were anesthetized) only after $20 \mathrm{~h}$ of exposition. The association of Cetamine base with Tiazine chloridrate did not improve the anesthesic effect, and higher concentrations of these drugs were toxic to the snails.

Sodium pentobarbital at $0.4 \mathrm{mg} / \mathrm{ml}$ in water for $8 \mathrm{~h}$ was the best treatment schedule to anesthetize Biomphalaria snails. In this schedule, the snails were anesthetized without any toxic effect. The procedure provides a powerful tool for in vivo studies that demande a complete state of snail anesthesia.

Key words: sodium pentobarbital - Biomphalaria - anesthesia - mollusc inoculation

The study of systematic, physiology, pharmacology and host-parasite relationship is compound by the lack of an efficient, simple and inexpensive method for anesthesia or muscle relaxing of gastropod molluscs.

Pan (1958) demonstrated that snail exposition to a menthol solution produce muscle relaxation in pulmonate molluscs, allowing a better tissue fixation aiming histological analysis. Michelson (1958) demonstrated that the best snail distension and immobilization was obtained through the immersion of snail in urethan aqueous solution. This methodology has been largely used in many mollusc species, however the technique does not permit snail manipulation, which demands a complete state of anesthesia. Runhan et al. (1965) concluded that anesthetic or narcotic drugs have a variable effect on mollusc, depending on the mollusc species tested, the drug concentration and the exposition time. Planorbidae molluscs are routinely relaxed by sodium pentobarbital in taxonomical and

This work was partially supported by Fapemig and $\mathrm{CNPq} /$ Pronex.

${ }^{+}$Corresponding author. Fax: +55-31-3499.2970. E-mail: denegrao@icb.ufmg.br

${ }^{++}$CNPq fellowship

Received 5 July 2000

Accepted 27 September 2000 systematical studies at the Department of Malacology of Instituto Oswaldo Cruz (Dr W Lobato Paraense, pers. comm.)

\section{MATERIALS AND METHODS}

Water-soluble drugs that had a reported anesthetic and/or narcotic effect on mice were selected to be tested in these experiments. Sodium pentobarbital (Hypnol®, Cristália, Brazil) was tested at $0.1,0.2,0.4,0.8,1.6 \mathrm{mg} / \mathrm{ml}$; sodium thiopental (Thionebutal ${ }^{\circledR}$, Abbot, Brazil) at 0.048, 2.5, 3.3 and $5 \mathrm{mg} / \mathrm{ml}$; cetamine base (Ketalar ${ }^{\circledR}$, ParkeDavis, Brazil) at $0.25,0.5$ and $0.75 \mathrm{mg} / \mathrm{ml}$ associated with chloridate 2-(2,6 xilidine)-5,6-dehidro$4 \mathrm{HI}, 3$ tiazine (Rompun ${ }^{\circledR}$, Bayer, Brazil) in a proportion of six parts of Ketalar to one part of Rompun as recommended for mice.

To each drug solution, ten Biomphalaria tenagophila, measuring $12-14 \mathrm{~mm}$ of diameter, were placed into a $500 \mathrm{ml}$ beaker with $100 \mathrm{ml}$ dechlorinated water containing the testing drug. The snails were kept into the drug solution and examined after 3, 5, 8 and $20 \mathrm{~h}$. The number of snail in each treatment that showed no effect, relaxation, anesthesia, or death was observed. A snail was considered relaxed if it had the cephalopodal region completely exposed but the animal slowly retracted when touched with a seringle needle. An anesthetized snail was defined as an animal that does not retract to the shell when injected, in cephalopodal region, with $10 \mu \mathrm{l}$ of PBS through a 21-G needle. After the inoculation the snails were 
transferred to another flask with water and the mortality was checked $24 \mathrm{~h}$ after inoculation.

\section{RESULTS AND DISCUSSION}

B. tenagophila exposed to all the tested concentrations of sodium thiopental showed immediate retraction, hemolymph lost and death. Snail retraction was also observed with cetamine alone at concentrations of 0.5 and $0.75 \mathrm{mg} / \mathrm{ml}$, or when associated with tiazine chloridrate.

Cetamine at $0.25 \mathrm{mg} / \mathrm{ml}$ was not toxic to the snails, however the relaxation occurred only after $8 \mathrm{~h}$ of exposition in $60 \%$ of the snails and complete anesthesia was observed in $40 \%$ of the $20 \mathrm{~h}$ exposed snails. All the cetamine anesthetized snails survived to the PBS inoculation. The association of $0.25 \mathrm{mg} / \mathrm{ml}$ of cetamine with $0.04 \mathrm{mg} / \mathrm{ml}$ of tiazine chloridrate did not improve the anesthetic effect obtained with cetamine alone, however tiazine chloridrate at concentrations higher than 0.1 $\mathrm{mg} / \mathrm{ml}$ were toxic to $B$. tenagophila.

Less than 10 and $20 \%$ of the snails exposed to 0.1 and $0.2 \mathrm{mg} / \mathrm{ml}$ of sodium pentobarbital showed muscle relaxation after $8 \mathrm{~h}$ (Table-A). However, all the snails exposed to $0.4 \mathrm{mg} / \mathrm{ml}$ of sodium pentobarbital were completely anesthetized after $8 \mathrm{~h}$, allowing experimental manipulation such as PBS inoculation. Snail exposition to higher drug concentration such as 0.8 and $1.6 \mathrm{mg} / \mathrm{ml}$ leads to snail mortality (Table-A).
The results showed that snail exposition to sodium pentobarbital at $0.4 \mathrm{mg} / \mathrm{ml}$ for $8 \mathrm{~h}$ was the most effective procedure to anesthetize $B$. tenagophila, with a very low mortality rate (TableB). The same treatment was also effective to anesthetize B. glabrata in our laboratory. The Hipnol ${ }^{\circledR}$ solution can be re-used 4 to 5 times, if filtered and kept at $4^{\circ} \mathrm{C}$. The treatment resulted in complete distention and relaxation of the snail muscle, allowing experimental manipulation in vivo, such as transplantation of internal organs, transference of hemolymph or cells from Schistosoma mansoni resistant snail strains to susceptible strains and other in vivo interference that may help to understand the interaction of S. mansoni and Biomphalaria spp.

\section{ACKNOWLEDGEMENTS}

To the GIDE (Schistosomiasis Research Unit) staff, for the technical support in the experiments.

\section{REFERENCES}

Michelson EH 1958. A method for relaxation and immobilitation of pulmonate snails. Trans Am $\mathrm{Mi}$ cros Soc 77: 316-319.

Pan CT 1958. The general histology and topographic microanatomy of Australorbis glabratus. Bull Mus Comp Zool Harvard 119: 237-299.

Runham NW, Isarankura K, Smith BJ 1965. Methods for narcotizing and anaesthetizing gastropods. Malacologia 2: 231-238.

\section{TABLE}

Effect of sodium pentobarbital on Biomphalaria tenagophila

A: snails analyzed after $8 \mathrm{~h}$ of exposition to different drug concentrations

\begin{tabular}{lcccc}
\hline $\begin{array}{l}\text { Concentrations } \\
(\mathrm{mg} / \mathrm{ml})\end{array}$ & $\begin{array}{c}\text { No effect } \\
(\%)\end{array}$ & $\begin{array}{c}\text { Relaxation } \\
(\%)\end{array}$ & $\begin{array}{c}\text { Anesthesia } \\
(\%)\end{array}$ & $\begin{array}{c}\text { Death } \\
(\%)\end{array}$ \\
\hline 0.1 & 90 & 10 & 0 & 0 \\
0.2 & 80 & 20 & 0 & 0 \\
0.4 & 0 & 0 & 100 & 0 \\
0.8 & 0 & 0 & 80 & 20 \\
1.6 & 0 & 0 & 30 & 70 \\
\hline
\end{tabular}

B: snails exposed to sodium pentobarbitol solution $(0.4 \mathrm{mg} / \mathrm{ml})$ and analyzed at different exposition time

\begin{tabular}{rcrrr}
\hline Exposition time (h) & $\begin{array}{c}\text { Without effect } \\
(\%)\end{array}$ & $\begin{array}{c}\text { Relaxation } \\
(\%)\end{array}$ & $\begin{array}{c}\text { Anesthesia } \\
(\%)\end{array}$ & $\begin{array}{c}\text { Death } \\
(\%)\end{array}$ \\
\hline 3 & 100 & 0 & 0 & 0 \\
5 & 0 & 100 & 0 & 0 \\
8 & 0 & 0 & 100 & 0 \\
20 & 0 & 0 & 0 & 100 \\
\hline
\end{tabular}

